\title{
Educating Engineering Students in Egypt: A Stakeholders' Perspective, Using Narrative Qualitative Approach
}

\author{
Ashraf Elsafty ${ }^{1}$, Hanaa ElSayad ${ }^{2}$, Ibrahim Shaaban ${ }^{3}$ \\ ${ }^{1}$ Adjunct Assistant Professor, Eslsca Business School, Paris, Egypt \\ ${ }^{2}$ Professor, Faculty of Engineering at Shoubra, 108 Shoubra St. Cairo, Egypt \\ ${ }^{3}$ Senior Lecturer, Civil Engineering and Built Environment, University of West London, UK \\ Correspondence: Ashraf Elsafty, Adjunct Assistant Professor, Eslsca Business School, Paris, Egypt. \\ https://orcid.org/0000-0002-9377-7286 \\ ORCID ID:
}

Received: June 16, 2020

doi:10.11114/jets.v8i8.4901
Accepted: July 10, $2020 \quad$ Online Published: July 13, 2020

URL: https://doi.org/10.11114/jets.v8i8.4901

\begin{abstract}
This is part of a series of three papers in a research project examining engineering education in Egypt. After concerns from several stakeholders about the graduates' knowledge and skills, a fresh look at the phenomenon is attempted. In this manuscript the views of stakeholders, using narrative approach and analysis was carried out. The methodology followed a narrative approach, conducting stakeholder's analysis with relevant and related people to engineering education (Coulter and Smith 2009; Sfard and Prusak, 2005). The sample included students \& fresh graduates, engineers with several years of experience, others with long experiences, academics, parents and administrative staff, were elicited. The responses were collected by asking two questions via social media. The aim was to obtain a quick idea on how stakeholders perceive engineering education in Egypt, and the enhancements they would like to see. Importance of the study comes from both linking with three papers in series exploring engineering education in Egypt, and the in-depth narrative reflections and insights of stakeholders' point of view. Four clear requests became evident from the stakeholders responses: the application of modern innovative teaching methods; soft skills training; modern software applications training; and practical technical or industrial training.
\end{abstract}

Keywords: higher education, Egypt, engineering education, quality, stakeholders, narrative method

\section{Introduction}

This publication is part of the research project series studying and discussing engineering education in Egypt. It supports the work published on the business perspective of engineering education (Elsafty, El Sayad, \& Shaaban, 2020, a) and recommendations for improvements (Elsafty, El Sayad, \& Shaaban, 2020, b). In general, as part of the quality assurance work in higher education, students are asked to complete a satisfaction survey. The results of this process should be used for continuous improvement of teaching but are almost never published. The authors cited only one published research paper on Egyptian engineering students' satisfaction. Ismail et al. (2017) examined the satisfaction of first and second year's students, who joined the newly established engineering education programmes in Alexandria and Helwan Universities. These new programmes were structured to apply quality assurance measures, where students are small in numbers, pay high fees for learning and the teaching is aimed to provide skills to match the job market. They noted that the satisfaction of the first and second year's students were 0.59 and 0.62 , whereas the similar cohort in the traditional programs, in which students only pay bench fees, was 0.61 and 0.65 , respectively.

To compare Egyptian students' satisfaction with that of students in international higher education, a small search was conducted. Students enrolled in top 20 UK universities expressed satisfaction levels between 67 and 89\% (Gibbons et al., 2015). Students enrolled in first year civil engineering courses at Cape Peninsula University of Technology in South Africa expressed between 0.72 to 0.88 satisfaction index with their courses (Miller et al., 2005). Sridhar and Sequeira (2007) conducted a student satisfaction survey at an Engineering College in India. They reported that satisfaction with teaching was 70\%. So, it appears that students in Egypt are slightly less satisfied than their international counterparts.

The common student satisfaction surveys usually ask students to evaluate the course, the instructor or educational establishment facilities, whereas graduates are asked to evaluate Alumni services. However, learners are not usually 
asked to indicate any deficiency they perceive in their acquired skills. The perspective of employers and professional engineers on the competency of fresh graduates is another issue rarely investigated or documented. The authors cited only one such study in Egypt. In her Msc. Thesis, Badawy (2009) investigated the views of senior architectural engineers working at three leading Egyptian design offices. The architects stressed the importance of studying humanities and computer applications. They also called for increasing practical training for students since fresh graduates are not prepared for work challenges.

In this paper, the views of different stakeholders, including fresh graduates and employers, were collected. This was not intended to be a detailed survey of how stakeholders perceive engineering education. The responses gave a very general idea about what stakeholders feel are the major flaws in Egyptian engineering education. The responses provided direction to examine the experiences of international engineering education providers to suggest the recommendations for improvement based on the pressing concerns of the Egyptian stakeholders.

Importance of the study comes from both linking with three papers in series exploring engineering education in Egypt, and the in-depth narrative reflections and insights from the stakeholders' point of view. In addition, the purpose goes beyond the traditional satisfaction surveys adopted in most quality assurance programmes. Stakeholders provided an assessment of the deficient skills in graduates. Based on the views collected herein, the recommendations for improvement were proposed after reviewing how international engineering education providers deal with the issues raised (Elsafty, Elsayad, \& Shaaban, 2020, b).

\section{Methodology and Results}

The research methodology followed a narrative approach, conducting stakeholder's analysis with relevant and related people to the engineering education (Coulter and Smith 2009; Sfard and Prusak 2005). The raised questions have been discussed in-depth with each stakeholder, using narrative qualitative approach, by discussions to ensure engagement with the stakeholder answering the questions. Starting by the secondary data gathering from relevant sources of the research context about engineering education in Egypt, then by narrative discussions collecting primary data from stakeholders. As narrative gives the ability to generate a meaningful outcome from the questions discussed in detail with the stakeholders.

A convenient sampling technique was followed, as of people acquainted with the authors, either personal friends or on the social media page of the Faculty of Engineering at Shoubra, were asked two questions:

1. What do you think is deficient in the engineering student experience today?

2. Do you have any suggestions to improve Egyptian Engineering Education?

Students \& fresh graduates, engineers with several years of experience, others with long experiences, academics, parents and administrative staff responded to the two questions. The detailed responses are shown in Appendix 1. Note that most of the responses were in Arabic and were translated by the authors. Responses were collected form the targeted stakeholders as follows:

- 26 Students and Fresh graduates

- 6 Graduate Engineers

- 10 Professional Engineers/Employers

- 8 Academic Staff

- 3 Administrative Staff

5 Parents

\section{Discussion}

\section{Summary of stakeholders' views on the deficiencies in student experience}

Input from the stakeholders gave various and valid perspectives on the deficiencies in current engineering education.

- Some instructors have poor teaching skills.

- No training for students in work setting/ practices.

- Instructor's knowledge is out of date.

- Graduates are shocked when they join industrial work as it is not directly related to what they studied.

- Graduates not familiar with new software.

- Students copy assignments. 
- Graduates recall what they studied, but unable to apply the knowledge.

- Graduates unable to make decisions.

- Graduates have no self-confidence.

- Graduates posse poor communication skills (writing, presentation....etc.)

- Graduates unable to operate simple office machines.

- Not enough open communication between students and instructors.

- Students are not asked to innovate.

- Graduates cannot persuade contractors or workers to do the job correctly.

\section{Stakeholders' suggestions and recommendations}

The stakeholders gave several recommendations. The recommendations were divided into two groups. Suggestions which cannot be applied at the moment, due to the internal or external constraints as discussed in Elsafty, El Sayad, \& Shaaban, (2020, a), and suggestions that are applicable. An analysis of the two groups is given below. In Elsafty, El Sayad, \& Shaaban, $(2020$, b), the authors tried to find how the latter suggestions can be implemented in Egypt by investigating the experience of international engineering education providers.

\section{A. Inapplicable suggestions}

There were a number of suggestions that cannot be applied as seen in Table 1 below. The authors gave reasons for their inapplicability. Further analysis of the constraints on Egyptian Engineering Education can be seen in Elsafty, A., El Sayad, H., \& Shaaban, I. (2020, a). 
Table 1. Inapplicable suggestions by stakeholders

\begin{tabular}{|c|c|}
\hline $\begin{array}{l}\text { Valid but constrained } \\
\text { suggestions }\end{array}$ & Why is this not applicable? \\
\hline Update the curriculum & $\begin{array}{l}\text { Only curriculum approved by the Supreme Council of Universities (SCU) and } \\
\text { Engineering Sector (ES) can be taught. SCU and ES have strict guidelines to avoid } \\
\text { delivering weak programmes }\end{array}$ \\
\hline $\begin{array}{l}\text { Change the grading and/or exam } \\
\text { system }\end{array}$ & This is part of the curriculum, cannot be changed \\
\hline $\begin{array}{l}\text { Improve/Evaluate the teaching } \\
\text { ability of academic staff }- \text { no } \\
\text { tenure for everyone }\end{array}$ & $\begin{array}{l}\text { There are programmes to support teaching competencies, but these need to become } \\
\text { more effective. This is beyond the control of individual faculties. Tenure is } \\
\text { garneted by Higher Education Law No. } 49 \text { issued } 1972 \text {. }\end{array}$ \\
\hline Improve school education & $\begin{array}{l}\text { This is the responsibility of the Ministry of Education, not the faculties of } \\
\text { engineering. }\end{array}$ \\
\hline $\begin{array}{l}\text { Update the academic background } \\
\text { of academic staff }\end{array}$ & $\begin{array}{l}\text { Criteria for hiring academic staff is set by Higher Education Law No. } 49 \text { issued } \\
1972 \text {. }\end{array}$ \\
\hline $\begin{array}{l}\text { Ethics of academic staff (selling } \\
\text { books, private tutoring are } \\
\text { amongst the undesirable } \\
\text { practices) }\end{array}$ & $\begin{array}{l}\text { Criteria for reprimanding academic staff is set by Higher Education Law No. } 49 \\
\text { issued } 1972 \text {. }\end{array}$ \\
\hline $\begin{array}{l}\text { Stop using authored academic } \\
\text { staff study books }\end{array}$ & $\begin{array}{l}\text { This is an undesirable practice. However, staff course notes, which students call } \\
\text { books, are sometimes the only source of study since many students cannot read } \\
\text { English sources. Some staff offer free notes, others ask students to pay printing } \\
\text { price. Unfortunately, some staff sell those at a profit. }\end{array}$ \\
\hline Stop private tutoring & $\begin{array}{l}\text { Any service without customers will cease to exist. The students keep up the } \\
\text { demand for tutoring since they got used to this during secondary school. The } \\
\text { faculties have no control on this practice since it is carried out outside working } \\
\text { hours and off campus. }\end{array}$ \\
\hline $\begin{array}{l}\text { Increase education fees paid by } \\
\text { students }\end{array}$ & $\begin{array}{l}\text { Many students cannot afford higher fees. Some even struggle to pay the bench fees. } \\
\text { It is a political decision beyond the control of the faculties of engineering. }\end{array}$ \\
\hline Reduce number of students & $\begin{array}{l}\text { SCU decides the number to be admitted to each faculty annually as discussed in } \\
\text { Part } 1\end{array}$ \\
\hline No old academic staff & Age discrimination is not acceptable. \\
\hline $\begin{array}{lll}\text { Close } & \text { private } & \text { engineering } \\
\text { faculties }\end{array}$ & Private faculties establishment is a political decision. \\
\hline $\begin{array}{l}\text { Give tax incentive to engineering } \\
\text { firms to cooperate in training } \\
\text { students }\end{array}$ & This cannot be controlled by the faculties of Engineering. \\
\hline $\begin{array}{l}\text { Change the Egyptian Codes of } \\
\text { Practice to be the same as } \\
\text { international codes }\end{array}$ & This cannot be controlled by the faculties of Engineering. \\
\hline Open courseware & $\begin{array}{l}\text { Developing E-Learning open courseware is costly and running these requires good } \\
\text { IT facilities which are not available in man faculties. }\end{array}$ \\
\hline $\begin{array}{l}\text { Train students to carry out } \\
\text { research }\end{array}$ & $\begin{array}{l}\text { Students need first to gain better English language ability to be able to read } \\
\text { research papers. Deficiency of lab facilities in some facilities may hinder practical } \\
\text { research. Post graduate students often conduct tests in large colleges or research } \\
\text { centers equipped with labs. Undergraduate will not be granted access to such } \\
\text { facilities. }\end{array}$ \\
\hline $\begin{array}{l}\text { Specialization, no need to study } \\
\text { many topics. Faculties for } \\
\text { designers and other for industry } \\
\text { supervisors. }\end{array}$ & $\begin{array}{l}\text { The undergraduate degree should give students a broad understanding of the } \\
\text { engineering field. Only curriculum approved by the Supreme Council of } \\
\text { Universities (SCU) and Engineering Sector (ES) can be taught. The Engineers } \\
\text { Syndicate only allows engineers with a BSc. in Engineering to join. Industry } \\
\text { supervisors will not find work as they are not members of the Syndicate. }\end{array}$ \\
\hline $\begin{array}{l}\text { Change the selection process for } \\
\text { academics }\end{array}$ & $\begin{array}{l}\text { Criteria for selecting academic staff is set by Higher Education Law No. } 49 \text { issued } \\
1972 \text {. }\end{array}$ \\
\hline $\begin{array}{lcc}\text { Change the } & \text { committees } \\
\text { responsible for } \\
\text { education in Egypt }\end{array}$ & That refers to SCU and ES. This is a political decision. \\
\hline Work and study & Study hours are set by the curriculum approved by SCU. \\
\hline
\end{tabular}




\section{B. Applicable suggestions from stakeholders}

By reviewing the responses in Appendix 1, four requests became clearly evident:

1. The application of modern innovative teaching methods, meaning improvement of teaching skills.

2. Soft skills training, including English language abilities

3. Modern software applications training

4. Practical technical or industrial training

\section{Analysis and Importance of the Stakeholders Requests}

\section{The application of modern innovative teaching methods}

Quoting from Patil and Prasad (2016):

"I hear and I forget. I see and I believe. I do and I understand. - Confucius

The above-mentioned famous statement clearly indicates the importance of using different tools rather than plain chalk and talk lecture. The impact of teaching in fact depends upon how many sensory organs are involved in the learning process. The innovative teaching methods aim at utilizing maximum sensory organs in learning activities."

Felder et al. (2000) recommended several techniques to increase the effectiveness of engineering teaching. These included:

"1. Formulate and publish clear instructional objectives.

2. Establish relevance of course material and teach inductively.

3. Balance concrete and abstract information in every course.

4. Promote active learning in the classroom.

5. Use cooperative learning.

6. Give challenging but fair tests.

7. Convey a sense of concern about students' learning."

Fiksl, Flogie and Abersek (2017) noted that students must be actively involved in the learning process during classes and that a positive environment must be created. This can be achieved by innovative teaching/learning methods such as problem-based learning, research based learning and participatory learning supported with information communication technology.

Felder (1987) wrote about the problems of the lecture - homework - quiz model in engineering education. He argued that this model is efficient in covering the syllabus but ineffective in producing creative problem-solving engineers. He conducted several "experiments" in his class to try to get the students to think divergently. He reported that the students were initially resistant to these exercises, but once they got the idea, they enjoyed solving the problems presented to them and the course evaluation was positive.

Rugarcia et al. (2000), pointed out that when we walk into an engineering class in the year 2000, we shall see the same as what we could have seen in 1940. "The professor stands at the front of the room, copying a derivation from his notes onto the board and repeating aloud what he writes. The students sit passively, copying from the board, reading, working on homework from another class, or daydreaming. Once in a while the professor asks a question: the student in the front row who feels compelled to answer almost every question may respond and the others simply avoid eye contact with the professor until the awkward moment passes. At the end of the class students are assigned several problems that require them to do something similar to what the professor just did or simply to solve the derived formula for some variable from given values of other variables. The next class is the same, and so is the next one and the one after that". They argued that there is a need to find new ways to teach engineers.

Berggren et al. (2003) wrote about an initiative to improve undergraduate engineering education. Four universities in Sweden and Massachusetts Institute of Technology (MIT) of the USA designed an instructing program which they called (CDIO) which stands for Conceiving - Designing - Implementing - Operating real-world systems and products. The curriculum includes assessment and evaluation tools. The CDIO program was applied in many universities worldwide and institution representatives reported their experiences in (Crawley, Malmqvist, Ostlund and Brodeur, 2007) and (Crawley, Malmqvist, Ostlund, Brodeur, and Edstrom, 2014). Unfortunately, Egyptian Engineering faculties do not have the freedom, or the resources to implement this curriculum.

It should be noted that with the establishment of NAQAAE in 2006, almost all academic faculty members in Egypt were lectured on modern teaching methods such as active learning, collaborative learning, problem-based learning, 
project based learning ... etc. However, NAQAAE lectures were theoretical and were prepared to be delivered to all faculties not just engineering. Staff did not receive any practical training on these teaching methods. Moreover, they are not aware of how to apply these methods in engineering courses.

\section{Soft skills training, including English language abilities}

Farr and Brazil (2009) were critical of the fact that the Grinter Report, published in 1955, is still the framework for engineering education in the USA. They also noted that the more recent report by the National Academy of Engineering issued in 2005 entitled "Educating the Engineer of 2020" recognized that the global marketplace is the key to the future of engineering. In addition, they quoted from this report "Technical excellence is the essential attribute of engineering graduates, but those graduates should also possess team communication, ethical reasoning, and societal and global contextual analysis skills as well as understanding work strategies."

Shuman, Sacre and McGourty (2005) classified the professional or soft skills into two categories: process skills and awareness skills. The process skills are: communication, teamwork, and ethical professional understanding. The awareness skills include: global, social, contemporary issue awareness and long life learning. They provided examples of how these skills are taught and reported that there is still work to be done in assessing these skills.

The term soft skills sometimes is interchanged with other expressions such as employability skills, key skills, transferable skills, basic skill, essential skills, work skills, core skills, core competencies and enabling skills or generic capabilities (Zaharim et al., 2009).

Perzigian (2013) emphasized the importance of delivering a higher education programme with in depth exposure to a diverse range of work in natural sciences, social sciences and humanities. This equips students with important competencies such as "critical thinking, knowledge integration, effective communication, and social responsibility. These competencies together with information literacy and quantitative/scientific reasoning are exactly what today's employers are seeking". He compared the percentage of credit hours of such general education courses required for graduation from the University of Cincinnati (USA) to those mandated by a typical Egyptian Engineering curriculum. He noted that Cincinnati students study only $49 \%$ of the program as engineering courses, whilst Egyptian students study around $90 \%$. Note that the accreditation criteria set by NAQAAE requires that humanities courses in engineering programs are allocated $10-12 \%$ of the credit hours. This renders the Egyptian graduates poorly prepared in terms of knowledge base and intellectual skills to be adaptable for inevitable change.

Schomaker (2015), on reviewing the skills deficit in Egyptian graduates, asserted that graduates should possess "writing and oral communication skills, skills in mathematics, research, decision-making, critical thinking, evaluation, computer work, teamwork and lifelong learning skills". She argued that these skills have to be obtained within the course of undergraduate study not after graduation, through extra training programs.

Pritchard and Nasr (2004) emphasized the importance of sound English language reading abilities for engineering students as most engineering publications are written in English. They argued that although students in Egypt learn English at school for 8 years before joining university, their teaching methods does not equip them with the necessary skills to read technical text. They described a study conducted at an engineering college in Egypt where the teaching methods for English instruction was changed, leading to positive outcome.

\section{Modern software applications training}

Seguin (2017) noted that in business environment nowadays people should have strong software skills, not only workplace skills that involve using email, word processing software, presentation software, and spreadsheet applications. Other skills such as database management, personal information management, and integration of data amongst programs are also important. Fasano (2011) added that in addition to Microsoft Office applications, students need to be very proficient in AutoCAD (Computer-Aided Design), especially mechanical and civil engineers because they will immediately use AutoCAD when they start work. These views were supported by Mraz (2017) who indicated that all engineers, not just software engineers, should be familiar with computer science fundamentals and data modeling. The former includes: data structures, algorithms, and computer memory manipulation, whilst the latter includes: estimating the dataset's underlying structures to identify useful patterns, identifying correlations between data, data clusters, detecting anomalies and regressions.

Adair and Jaeger (2011) asserted that there is a pressing need to include computer-assisted learning into engineering education, both as a learning aid and for professional training.

El Bahrawy (2005) also stressed the importance of utilizing computers in teaching engineering courses. He noted that this can take many forms: 
a) Teaching students to write computer programs using programming languages such as Basic, Fortran, Pascal and $\mathrm{C}++$.

b) Teaching students to use specialized commercial software packages like those developed for project management, structural design and solving pipeline networks.

c) Utilizing general software such as Microsoft Excel in solving engineering cases by designing spread sheets for particular problems.

Typically, computers and software applications are part of the curriculum in Egyptian faculties of engineering. In the preparatory year students are taught a course titled "Introduction to computers and basic programming". In the first year, students study another course under the name "Computer programming and windows-based applications". During the second year, students are taught "Computer applications" and finally an elective in the fourth and final year called "Advanced computer applications" is available. Although this may seem adequate, in reality the authors have the following reservations:

- During the preparatory year, all students admitted to the faculty of engineering attend the course. The number is always much more than the available computers on campus. This transforms the course into a theoretical study and hardly any practical training takes place.

- When students join the various departments in the first year, they are not usually well prepared to start practical work to apply what they should have learned in the preparatory year. A repeat of the basic principles is usually covered.

- To effectively teach computer applications, the second year course, there should be two conditions: first the commercial software packages would need to be available on campus computers for training, and second the student should have studied enough specialized courses in order for him/her to use the commercial software in generating solutions. As both of these conditions are usually absent, the course usually covers more programming.

- For effective learning, all courses should teach topics in computer applications related to the course theme. This is not always practical again due to the relatively large number of students and lack of specialized software on campus. In addition, many topics need to be covered during $3^{\text {rd }}$ or $4^{\text {th }}$ year syllabuses, leaving little time to teach computer applications as well.

- Students studying the elective course in the final year benefit from having studied sufficient engineering specialized courses, and they are usually eager to generate computer solutions. Those who are keen usually acquire a laptop and upload open source programs and start practicing. Economic difficulties make owning a laptop impossible for many students.

Because of the above-mentioned circumstances, engineers often graduate without solid software training. Many students supplement this deficiency by enrolling in software courses offered by private providers off campus. Some faculties offer software courses on campus through the Engineering Consultancy Services. These are open to any members of the community. However, many students cannot afford to pay the fees needed to attend those courses.

\section{Practical technical or industrial training}

Patrick et al. (2009) conducted a series of industry and work-related employer interviews. They concluded that: "project work can be utilized to provide learning experiences which highlight the relevance of the degree to a particular industry." Therefore, practical projects like the graduation projects, can be designed to expose students to experience workplace environments and personal interactions as part of their learning experience.

Employers distinguish between hard skills or job-specific skills which are closely connected with knowledge and observed and easily measured, and 'soft' skills which are non-job specific skills including ethics, communication, team-based work, management, and entrepreneurial skills (ABET, 2015). Chikumba (2011) suggested that the development of "hard engineering skills, which include computation, analysis, and design, could be achieved through a combination of tuition and work integrated learning".

Kramer and Usher (2011) defined work integrated learning (WIL) as: "Work-Integrated Learning (WIL) refers to types of student employment experiences that are usually organized by their institution, related to their field of study and geared toward making connections between classroom learning and on-the-job experiences." They pointed out that this is a structured learning experience, which add value to technical skills, unlike the general career benefits that are obtainable from other types of student work experiences. The formats of WIL can be research, internships, study abroad, service learning, student teaching, clinical rotations, community service, industry attachments, cooperative education, and professional work placements. The types of WIL can be: pre-course experience, sandwich courses, co-operative 
courses, cognitive apprenticeship or job shadowing, joint industry-university courses, new traineeships and apprenticeships, placement or practicum, fieldwork, and post-course internship.

Male and King (2104) provided and extensive guide on how to conduct practical training for engineering students. They noted that engineering education is usually focused on engineering science rather that application and practice. However, they stressed that training reduces skills shortage and improves graduates' employability. Their report provided recommendations to engineering faculties, industry, professional bodies and governments.

Neill, and Mulholland, (2003) noted that practical training can take many forms: sandwich placements, work based projects, work placements, voluntary work, part time work, work shadowing or internships. Ulster University, where those authors work, issued a document entitled: "Policy for good practice for all courses incorporating an element of work experience" in 2001. They quoted from that document that the main objectives of practical training are:

"• to enhance students' familiarity with the world of work and enable them to reflect constructively on issues related to work;

- to assist students to evaluate and understand how work experience relates to their personal/career and future professional development;

- to develop employability skills, intellectual skills, core or key skills, personal attributes, knowledge about how organisations work;

- to consolidate, complement and extend the academic programme and enable the essential integration of clinical/professional practice;

- to maintain and develop links between the university, the placement provider and the community; and

- to develop clinical/professional skills and to strengthen the application of theory to practice."

Bhurtun et al. (1999) reported that the students who took part in a 3 month structred training in an electric engineering programme after the first year, maintained a constantly better performance in subsequent years and attained remarkable standard for their final year projects, as well as in their career as professional engineers.

Meenaloshini et. al. (2014) noted that: "Industrial training is a form of contested learning, meaning ambiguity and conflict between what is espoused and what is practiced in either the workplace and /or the university or college classroom. Contested learning in industrial training reflects competing interest (economic, educational and personal) that are found in the actions and values of students, teaching staff or workplace supervisor."

For practical training, engineering students in Egypt are required to undertake 8 weeks of training during the summer holidays. Usually this is devided into two 4 week periods. In the first 4 weeks, usually after the first year of study, students are trained on campas to gain skills in engineering drawing or surveying for example. The second 4 weeks, during any summer before the final year in engineering, requires training at an actual work location. Usually the student brings to the faculty a letter that he had attended the training from the work entity. Training is a requirement for graduation, but it does not count towards any marks or credit hours. With large student numbers, supervision from faculty staff is not always practical.

\section{Conclusions}

1. A narrative qualitative approach was followed to gather information about the views of stakeholders regarding engineering education in Egypt.

2. Data collection was conducted via social media. A convenient sampling technique was adopted. The aim was to get a quick idea on the changes stakeholders want to see in Egyptian engineering education.

3. Some of the suggestions of stakeholders were inapplicable due to internal and external constraints as discussed in Elsafty, El Sayad, \& Shaaban, (2020, a).

4. The stakeholders identified four requests namely: the application of modern innovative teaching methods; soft skills training; modern software applications training; and practical technical or industrial training.

5. The importance of stakeholders requests was validated by screening published research form education specialists.

6. In Elsafty, Elsayad, \& Shaaban (2020, b)., a review of international engineering education experiences was made to select the possible practices that can be implemented in Egypt to realize the stakeholders aspirations. 


\section{References}

ABET. (2015). Criteria for accrediting engineering programs. Retrieved from http://www.abet.org/accreditation/accreditation-criteria/criteria-for-accreditingengineering-programs-2015-2016

Adair, D., \& Jaeger, M. (2011). Integration of computational fluid dynamics into a fluid mechanics curriculum. Computer Applications in Engineering Education, 22(1), 131-141. https://doi.org/10.1002/cae.20539

Badawy, M. A. Y. (2009). The relationship between university architectural education and practicing the profession of architecture. Msc. Thesis, Ain -Shams University, Egypt. Available at: http://www.cpas-egypt.com/AR/Manal_ar.html (In Arabic)

Berggren, K. F., Brodeur, D., Crawley, E. F., Ingemarsson, I., Litant, W. T. G., Malmqvist, J., \& Östlund, S. (2003). CDIO: An international initiative for reforming engineering education, World Transactions on Engineering and Technology Education, 2(1). Available at http://citeseerx.ist.psu.edu/viewdoc/download?doi=10.1.1.113.2987\&rep=rep1\&type=pdf

Bhurtun, C., Jahmeerbacus, I., Oolun, K., \& Feliachi, A. (1999). Short-term practical training for electrical engineering undergraduates. IEEE Transactions on Education, 42(2), 109-113. https://doi.org/10.1109/13.762938

Chikumba, S. (2011). Development of soft engineering skills for industrial engineering technologists through effective mentoring. Paper presented at the WACE 17th World Conference on Cooperative and Work Integrated Education, Philadelphia, PA. Retrieved from http://www.waceinc.org/philly2011/conference_proceedings/Refereed\%20Papers/South\%20Africa/STEADY 1.P $\mathrm{DF}$

Coulter, C. A., \& Smith, M. L. (2009). The Construction Zone: Literary Elements in Narrative Research. Educational Researcher, 388, 577-590. https://doi.org/10.3102/0013189X09353787

Crawley, E. F., Malmqvist, J., Ostlund, S., \& Brodeur, D. R. (2007). Rethinking engineering education: the CDIO approach. $1^{\text {st }}$ Ed. Springer International Publishing Switzerland. ISBN 0387382879

Crawley, E. F., Malmqvist, J., Ostlund, S., Brodeur, D. R., \& Edstrom, K. (2014). Rethinking engineering education: the CDIO approach. $2^{\text {nd }}$ Ed. Springer International Publishing Switzerland. https://doi.org/10.1007/978-3-319-05561-9_2

El Bahrawy, A. N. (2005). The use of computers through a systematic approach to develop engineering education in the area of water resources. Paper presented at the $5^{\text {th }}$ Arab Conference - Systematic Approach in Teaching and Learning, Cairo, April 2005, pp. 286-297. Retrieved from https://search.mandumah.com/Record/31315

Elsafty, A., El Sayad, H., \& Shaaban, I. (2020a). A Business Analysis Perspective for Engineering Education in Egypt. Journal of Education and Training Studies. https://doi.org/10.11114/jets.v8i5.4721

Elsafty, A., El Sayad, H., \& Shaaban, I. (2020b). Educating Engineering Students in Egypt: Recommendations forImprovement. International Journal of Higher Education. https://doi.org/10.5430/ijhe.v9n3p1

Farr, J. V., \& Brazil, D. M. (2009). Leadership skills development for engineers. Engineering Management Journal, 2(1), 3-8. https://doi.org/10.1080/10429247.2009.11431792

Fasano, A. (2011, August 24). Computer Skills that An Engineer Should Have to Advance their Engineering Career. Engineering Management Instituter from https://engineeringmanagementinstitute.org/computer-skills-that-an-engineer-should-have-to-advance-their-engine ering-career/

Felder, R. M. (1987). On creating creative engineers. Engineering Education, 77(4), 222-227. Available at http://www4.ncsu.edu/unity/lockers/users/f/felder/public/Papers/Creative_Engineers.pdf

Felder, R. M., Woods, D. R., Stice, J. E., \& Rugarcia, A. (2000) The future of engineering education. II. Teaching methods that work. Chemical Engineering Education, 34(1), 26-39. Available at https://www.researchgate.net/profile/Richard_Felder/publication/2628093_The_Future_Of_Engineering_Educatio n_Ii_Teaching_Methods_That_Work/links/54b7e5c00cf28faced60c579.pdf

Fiksl, M., Flogie, A., \& Aberšek, B. (2017). Innovative teaching/learning methods to improve science, technology and engineering classroom climate and interest. Journal of Baltic Science Education, 16(6), Retrieved from http://oaji.net/articles/2017/987-1513971461.pdf

Gibbons, S., Neumayer, E., \& Perkins, R. (2015). Student satisfaction, league tables and university applications: Evidence from Britain. Economics of Education Review, 48, 148-164. 
https://doi.org/10.1016/j.econedurev.2015.07.002

Higher Education Law No. 49 issued 1972 Available at http://www.du.edu.eg/files/\%D9\%82\%D8\%A7\%D9\%86\%D9\%88\%D9\%86\%20\%D8\%AA\%D9\%86\%D8\%B8\% D9\%8A\%D9\%85\%20\%D8\%A7\%D9\%84\%D8\%AC\%D8\%A7\%D9\%85\%D8\%B9\%D8\%A7\%D8\%AA\%20\%D8 \%A7\%D9\%84\%D9\%85\%D8\%B5\%D8\%B1\%D9\%8A\%D8\%A9.pdf

Ismail, M. F., Moscardini, A., \& Elsamadicy, A. M. (2017). A dynamic modelling of the key quality management students' satisfaction in the Egyptian public higher education. The Business and Management Review, 8(5), 294-304.

Kramer, M., \& Usher, A. (2011). Work-Integrated Learning and Career-Ready Students: Examining the Evidence, Toronto: Higher Education Strategy Associates. Retrieved from http://higheredstrategy.com/wp-content/uploads/2011/11/InsightBrief5-FINAL-1.pdf

Male, S., \& King, R. (2014). Best practice guidelines for effective industry engagement in Australian Engineering degrees. Australian Council of Engineering Deans Inc, Retrieved from: https://www.researchgate.net/profile/Sally_Male/publication/312068210_Best_Practice_Guidelines_for_Effective_ Industry_Engagement_in_Australian_Engineering_Degrees/links/586de37208ae6eb871bcf240/Best-Practice-Guid elines-for-Effective-Industry-Engagement-in-Australian-Engineering-Degrees.pdf

Meenaloshini, S., Linda, C., Zaimah, H., Noor Zaimah, M., \& Noor, Z. (2014). An analysis on the implementation of industrial training for mechanical engineering students in uniten, International Journal of Asian Social Science, 4(5), 664-669.

Miller, S., Haupt, T. C., \& Chileshe, N. (2005). Student perceptions of the first year civil engineering course content, Journal of Engineering, Design and Technology, 3(2), 180-189. https://doi.org/10.1108/17260530510815402

Mraz, S. (2017, July 21). Master these technical and soft skills to ensure continued professional success. Machine Design, Retrieved from https://www.machinedesign.com/community/10-must-have-skills-all-engineers

Neill, N. T., \& Mulholland, G. E. (2003). Student placement - structure, skills and e-support. Education + Training, 45(2), 89-99. https://doi.org/10.1108/00400910310464062

Patil, S. A., \& Prasad. S. R. (2016). Innovative Methods of Teaching \& Learing Electronics Engineering. Journal of Engineering Education Transformations. https://doi.org/10.16920/jeet/2016/v0i0/85656

Patrick, C. J., Peach, D., Pocknee, C., Webb, F., Fletcher, M., \& Pretto, G. (2009). The WIL [Work Integrated Learning] report: A national scoping study [Australian Learning and Teaching Council (ALTC) Final Report]. Brisbane, Qld, Australia: Queensland University of Technology. Retrieved from: http://www.olt.gov.au/system/files/grants_project_wil_finalreport_jan09.pdf

Perzigian. A. J. (2013, April 3). Higher education reform in post-revolution Egypt. Egypt Independent. Retrieved from http://www.egyptindependent.com/higher-education-reform-post-revolution-egypt/

Pritchard, R. M. O., \& Nasr, A. (2004). Improving reading performance among Egyptian engineering students: principles and practice. English for Specific Purposes, 23, 425-445. Available at http://0810156pd.1103.y.ttps.ac.els-cdn.com.mplbci.ekb.eg/S0889490604000031/1-s2.0-S0889490604000031-mai n.pdf?_tid=82075798-ab74-11e7-975f-00000aacb35d\&acdnat=1507390434_df4e7fb1e4d6f9dbbc777176e870f2f6

Rugarcia, A., Felder, R. M., Woods, D. R., \& Stice, J. E. (2000). The future of engineering education. I. A vision for a new century. Chemical Engineering Education, 34(1), 16-25. Available athttp://www4.ncsu.edu/unity/lockers/users/f/felder/public/Papers/Quartet1.pdf

Schomaker, R. (2015). Accreditation and quality assurance in the Egyptian higher education System. Quality Assurance in Education, 23(2), 149-165. https://doi.org/10.1108/QAE-08-2013-0034

Seguin, D (2017, July 7). Teaching Computer Applications to First-Year Students-The First Class. Paradigm Education Solutions. Retrieved from https://paradigmeducation.com/2017/07/07/teaching-computer-applications-first-year-students-first-class/

Sfard, A., \& Prusak. A. (2005). Telling Identities: In Search of an Analytic Tool for Investigating Learning as a Culturally Shaped Activity. Educational Researcher, 344: 14-22. https://doi.org/10.3102/0013189X034004014

Shuman, L. J., Sacre, M. B., \& McGourty, J. (2005). The ABET "Professional Skills" - Can they be taught? Can they be assessed? Journal of Engineering Education, 94(1), 41-55. https://doi.org/10.1002/j.2168-9830.2005.tb00828.x

Sridhar, S., \& Sequeira, A. H. (2007). Student Satisfaction Survey in an Engineering College in India - A Case Study. 
The Indian Journal of Technical Education, 30(1), 31-39.

Zaharim, A., Yusoff, Y. M., Omar, M. Z., Mohamed, A. Muhamad, N., \& Mustapha, R. (2009). Employers perception towards engineering employability skills in Asia. WSEAS Transactions on Advances in Engineering Education, 6(9), 306-315.

\section{Appendix 1 - Stakeholders Views}

Students and Fresh graduates

- I believe that we need to update our curriculums, train our teachers on how to motivate not stimulate, and change our evaluation from 30\% classwork - 70\% final exam, to be the opposite. Add more value to practicing.

- There must be a practical site implementation part during undergraduate study. This part should be graded. Software teaching is ignored. Students should learn software within the faculties instead of having to learn that through external courses. There must be individual and group project work related or with all taught courses.

- The academic competency of faculty member and teaching assistance should be given careful consideration. Sometimes the faculty members are proficient in the scientific topics, but unable to teach effectively.

- Pre university education should be developed.

- Students should implement what they have learned in the industry. I suggest one month of lectures, alternating with one month on site to apply what has been learned in lectures. Greater emphasis should be on what the engineers will need once they graduate like technical office work, bids, work implementation, report writing, communication by emails and soft skills. The mind set and scientific thinking of faculty staff should be up to date. Some faculty members are stuck in 1985 . Continuous improvement is essential.

- Theoretical courses should be replaced by learning to use engineering computer programs. Compulsory practical training for all students at work sites should be arranged by the faculty every year for all students. This should be under the supervision of the faculty and should be graded. Student course evaluation should be carried out all the time. Faculty members should present to their students all new innovations in their fields.

- The process and history of each of the engineering theories should be explained to students. This should be followed by practical application of these theories. The application should be clear, so that there will be no room for ambiguity or misunderstanding in any way.

- Stress practical applications.

- Renew the curriculum by adding modern software used in design.

- Management and implementation of the work in the faculty should be improved.

- Links must be established between academia and practical application. This should be a serious controlled link. We were all shocked by real practice after graduation.

- Applications should be on real life problems. Choices should be based on student talents not his GPA (The student is probably referring to the departments within the faculty of engineering. Students are allocated to various departments based on preparatory year GPA. Those with higher GPA choose which department they go to.)

- Connecting the study in the faculty with practical life.

- Practice, practice, practice!!!! Students should be trained before graduation under the supervision of the faculty.

- Graduate engineers should come to teach in the faculty for one year.

- Curriculum update, practical applications and better selection and training of faculty members.

- The T-Square (ruler) should be placed on exhibit at the Egyptian museum (joke).

- Thank you for asking this question. The faculty member has the greatest responsibility in the engineering education system. The student is at a critical life stage and needs added value from the teacher. The value of science and the value of his word. Faculty member should posses these values to transmit them to students. His role should never be to fill students' brains with information in order to pass the lecture time.

- Students should work during studying. Four days of studying and two days at work. 
- Everything is on its way to becoming automated. It is important that students learn programming for all engineering specialties. These should be trained in new technology like BIM in construction.

- The study curriculum should be linked with practical application. Students should be really practically trained and their skills in management, communication and languages should be developed.

- The guidelines of NAQAAE in terms of faculty/student ratio should be followed. Practical training should be compulsory and graded. No printing of educational books authored by staff members. No discrimination of a student who bought the book and the one who did not. No private tutoring.

- Sending people to study abroad with the help of business men.

- The students should be taught creativity, innovation and development skills. They should be introduced to economic growth ideas.

- Reform of the curriculum. Hire staff that can keep up with the technological development. Compulsory practical training for 4 months annually during the 5 years of engineering study. Increasing the fees paid by student to cover the real cost of education. Reducing the number of admitted students.

- Abolish the faculties of engineering altogether. Linking the job market to any market, no problem (sarcastic remark).

Graduate Engineers

\begin{tabular}{|c|c|c|}
\hline No. & Attributes & Response \\
\hline 1 & $\begin{array}{l}\text { Graduated in late 1990's from Cairo } \\
\text { University, worked in construction } \\
\text { contracts department at a large } \\
\text { consulting office, recently moved to } \\
\text { Canada and trying to get the Egyptian } \\
\text { degree recognized. }\end{array}$ & $\begin{array}{l}\text { I am now studying the same typical traditional curriculum in Canada } \\
\text { in order to sit for the professional engineers exam. It seems that the } \\
\text { situation is the same everywhere, theory is more important than } \\
\text { practice to academics. Engineers do not need this in practice. Why are } \\
\text { students still taught engineering drawing the same old way, when } \\
\text { there are now many software packages like Autocad? Graduates } \\
\text { should be ready to use these all such computer applications. }\end{array}$ \\
\hline 2 & $\begin{array}{l}\text { Graduated in 2010's form Shoubra } \\
\text { worked in Saudi Arabia and Egypt. }\end{array}$ & $\begin{array}{l}\text { The old curriculum should be reformed. New teaching methods } \\
\text { should be applied. Faculty staff members over } 50 \text { years of age should } \\
\text { not teach fresh students. Annual applied projects should be } \\
\text { implemented by students in parallel with studying. Scientific research } \\
\text { should be encouraged and psychological rehabilitation is needed. }\end{array}$ \\
\hline 3 & $\begin{array}{l}\text { Graduated in early } 2000 \text { 's form Shoubra } \\
\text { worked in Egypt and the Gulf in } \\
\text { Multinational companies }\end{array}$ & $\begin{array}{l}\text { First, all private engineering faculties should be closed. Second, } \\
\text { engineering education is not about copying answers to assignments } \\
\text { form the library. In engineering education the student should gain } \\
\text { skills and understanding. The assignment should measure the } \\
\text { students' ability for creativity and innovation. Students only } \\
\text { memorize. If you ask them about any concept, they recite what has } \\
\text { been memorized. On site however, they cannot make any decision or } \\
\text { even present a suggestion. }\end{array}$ \\
\hline 4 & $\begin{array}{l}\text { Graduated in early 2000's form Shoubra } \\
\text { worked in Egypt and the Gulf }\end{array}$ & $\begin{array}{l}\text { There should be open courseware for all courses. Faculty staff } \\
\text { members should be evaluated in accordance with their participation in } \\
\text { open courseware during promotion to higher academic degrees. Part } \\
\text { of the students' grades should be for scientific research and they } \\
\text { should be familiar with international journals and able to look up } \\
\text { information. Final year projects should be for Egyptian national needs } \\
\text { like solar panels, modern building materials which consume less } \\
\text { energy during manufacturing, and industrial design. There should be a } \\
\text { mechanism to link local companies to the universities in order to help } \\
\text { in training students. In return the companies can be granted tax } \\
\text { incentives or any other means of motivation. }\end{array}$ \\
\hline 5 & $\begin{array}{l}\text { Graduated mid 2000's form Shoubra, } \\
\text { worked in Egypt and the Gulf }\end{array}$ & $\begin{array}{l}\text { During graduation projects, students should work on industrial site to } \\
\text { build their true professional character. }\end{array}$ \\
\hline 6 & $\begin{array}{l}\text { Graduated mid 2000's form Tanta } \\
\text { University, worked in Egypt and the } \\
\text { Gulf }\end{array}$ & $\begin{array}{l}\text { Each student should choose a large important project and go the site to } \\
\text { collect information. Then the student discusses this information with } \\
\text { the faculty member. }\end{array}$ \\
\hline
\end{tabular}


Professional Engineers/Employers

\begin{tabular}{|c|c|c|}
\hline No. & Attributes & Response \\
\hline 1 & $\begin{array}{l}\text { Graduated late } 1980 \text { 's from } \\
\text { Kuwait university and worked } \\
\text { in a government engineering } \\
\text { company in Egypt for many } \\
\text { years. }\end{array}$ & $\begin{array}{l}\text { The best way is to make practical technical training a study course after the } \\
\text { first year. Each year the students should be trained on a specific topic. }\end{array}$ \\
\hline 2 & $\begin{array}{l}\text { Graduated early 1990's, } \\
\text { working in a conglomerate of } \\
\text { firms in Egypt in a leadership } \\
\text { position }\end{array}$ & $\begin{array}{l}\text { 1. Concentrating so much on REAL and SERIOUS on- job training at factories } \\
\text { and production lines for considerable periods. Swedi industries are } \\
\text { implementing this with great success. } \\
\text { 2. Continuous wide exposure to technical training content present on digital } \\
\text { media like YouTube and Google general content where they present new } \\
\text { development and new gadgets used in technology, manufacturing and technical } \\
\text { design offices. }\end{array}$ \\
\hline 3 & $\begin{array}{l}\text { Graduated } 1970 \text { 's, emeritus } \\
\text { professor at Cairo University } \\
\text { and owner of an engineering } \\
\text { consulting office }\end{array}$ & $\begin{array}{l}\text { The pre university education should be improved and by that half the problems } \\
\text { would be resolved. }\end{array}$ \\
\hline 4 & $\begin{array}{l}\text { Graduated in the early 1990's } \\
\text { from Alexandria University. } \\
\text { Worked in various firms in } \\
\text { Egypt }\end{array}$ & $\begin{array}{l}\text { The curriculum and teaching methods should be changed. There should be } \\
\text { emphasis on research and understanding not memorizing. There should be } \\
\text { courses for critical thinking and problem solving. The graduation project } \\
\text { should be individual not group work and must be about a new idea, invention } \\
\text { or product instead of being a copy from other sources. Graduation projects } \\
\text { should find solutions to real problems. The theoretical part in exams should be } \\
\text { replaced by questions that depend on analysis and understanding. Proper } \\
\text { selection of faculty staff based on merit. }\end{array}$ \\
\hline 5 & $\begin{array}{l}\text { Graduated mid } 1980 \text { 's from } \\
\text { Cairo University, worked in } \\
\text { international contractor's firms } \\
\text { in Egypt and now working in } \\
\text { Qatar }\end{array}$ & $\begin{array}{l}1 \text { - Presentation skills } \\
2 \text { - Report writing } \\
3 \text { - Official letters / contractual }\end{array}$ \\
\hline 6 & Engineer over 55 years of age. & $\begin{array}{l}\text { The engineer must be proficient in software packages. He must know how to } \\
\text { operate a printer on a network. He must be able to read blue prints. He must be } \\
\text { at least able to write a report to state what he wants. It is not acceptable that I } \\
\text { find engineers who do not know to carry out any of these simple tasks. }\end{array}$ \\
\hline 7 & $\begin{array}{l}\text { Graduated early 1980's from } \\
\text { Kuwait university and worked } \\
\text { in the Gulf and in Egypt on } \\
\text { large projects }\end{array}$ & $\begin{array}{l}\text { 1. Constant update of curriculums to match technology updates and market } \\
\text { needs. } \\
\text { 2. Practical on-site training/internship at reputable companies that is } \\
\text { compulsory and supported by faculty management. }\end{array}$ \\
\hline 8 & $\begin{array}{l}\text { Graduated mid 1980's from } \\
\text { Ain Shams University and } \\
\text { worked in international } \\
\text { consulting offices in Egypt and } \\
\text { the Gulf }\end{array}$ & $\begin{array}{l}\text { 1. The global market requirements should be taken into considerations. } \\
\text { 2. Engineering education should cover international codes of practice, not } \\
\text { just the Egyptian codes. } \\
\text { 3. Computer should be taught in all subjects. }\end{array}$ \\
\hline 9 & $\begin{array}{l}\text { Graduated early 1970's, } \\
\text { worked in Egypt and also for } \\
\text { many years in the Gulf }\end{array}$ & $\begin{array}{l}\text { We should have two types of faculties of engineering. One should be devoted } \\
\text { to teaching designers and the other should teach industry supervisors. } \\
\text { Emphasis should be placed on specialization, no need to teach all civil } \\
\text { engineering students railways, sea ports, highways, steel bridges and then they } \\
\text { end up only working in the construction of reinforced concrete buildings. } \\
\text { Specialization is currently very important. }\end{array}$ \\
\hline 10 & $\begin{array}{l}\text { Graduated early 1980's from } \\
\text { Kuwait university and working } \\
\text { as a trainer for fresh graduates }\end{array}$ & $\begin{array}{l}\text { A lot of practice in the laboratories is important. Students must see everything } \\
\text { and they should be trained with the help of the university in accordance with } \\
\text { their departments. }\end{array}$ \\
\hline
\end{tabular}


Academic Staff

\begin{tabular}{|c|c|c|}
\hline No. & Attributes & Response \\
\hline 1 & $\begin{array}{l}\text { Professor at the Faculty of Engineering - } \\
\text { Cairo University, now working at UEA }\end{array}$ & $\begin{array}{l}\text { Faculties of engineering, all laboratories and scientific research } \\
\text { should be linked to the industry and government ministries. } \\
\text { Scientific research should be encouraged. Curriculum should } \\
\text { address understanding not memorizing. }\end{array}$ \\
\hline 2 & $\begin{array}{l}\text { Assistant professor, originally from Cairo } \\
\text { University, but has now moved to Nile } \\
\text { University and has taught courses in } \\
\text { international universities in Egypt and } \\
\text { abroad }\end{array}$ & $\begin{array}{l}\text { Hire professors after } \mathrm{PhD} \text { on a competitive basis and do not give } \\
\text { them tenureship until they earn it. }\end{array}$ \\
\hline 3 & $\begin{array}{l}\text { Professor at the Faculty of Engineering - } \\
\text { Cairo University }\end{array}$ & $\begin{array}{l}\text { All those responsible for engineering education in Egypt should be } \\
\text { changed including the engineering sector committee. } \\
\text { Note: the engineering sector committee has to approve curriculums } \\
\text { before implementation, and usually stands in the way of any } \\
\text { unconventional courses. }\end{array}$ \\
\hline 4 & $\begin{array}{l}\text { Professor at the Faculty of Engineering } \\
\text { Shoubra }\end{array}$ & $\begin{array}{l}\text { Education should be student oriented not teacher oriented. Pull } \\
\text { education instead of push education. }\end{array}$ \\
\hline 5 & $\begin{array}{l}\text { Assistant professor at Faculty of } \\
\text { Engineering Helwan University. } \\
\text { Contributed to education development } \\
\text { efforts for many years }\end{array}$ & $\begin{array}{l}\text { Continuous training for the staff. Internship with the labour market. } \\
\text { Quality of the education and management. Continuous development } \\
\text { of the Curricula. Link education with labour market. }\end{array}$ \\
\hline 6 & $\begin{array}{l}\text { Professor in a leadership position at } \\
\text { Fayoum University }\end{array}$ & $\begin{array}{l}\text { Practical applications depending on department specialty. } \\
\text { Faculties acquiring new software for student training. }\end{array}$ \\
\hline 7 & $\begin{array}{l}\text { Professor in a leadership position at } \\
\text { Shoubra }\end{array}$ & $\begin{array}{l}\text { Reduce the number of students per class. Students should explain } \\
\text { some parts of the lectures to promote self learning. Efficient use of } \\
\text { laboratories by asking students to carry out laboratory assignments } \\
\text { and projects. Improve students skills by not depending on the lecture } \\
\text { mode of learning }\end{array}$ \\
\hline 8 & Emeritus professor at Cairo University & $\begin{array}{l}\text { Faculties on engineering should be aligned with the international } \\
\text { development in engineering sciences and should be ultimately aimed } \\
\text { at societal development }\end{array}$ \\
\hline
\end{tabular}




\section{Administrative Staff}

\begin{tabular}{l|l|l}
\hline No. & Attributes & Response \\
\hline 1 & $\begin{array}{l}\text { Has been working in } \\
\text { the Shoubra for more } \\
\text { than 20 years. }\end{array}$ & $\begin{array}{l}\text { When a student is accepted in the faculty of engineering, he should undergo ethical } \\
\text { training by faculty staff members. This enables the student to respect intellectual capital } \\
\text { and teaches him the importance of scientific research. After this training, students can be } \\
\text { allocated to departments depending on their aptitude. }\end{array}$ \\
\hline 2 & $\begin{array}{l}\text { Has been working in } \\
\text { the Shoubra for more } \\
\text { than 20 years. }\end{array}$ & $\begin{array}{l}\text { There is a gap between students and faculty staff. Students should be consulted in a } \\
\text { number of issues. Rapport should be build between students and faculty so that students } \\
\text { can ask about what they do not understand without hesitation. Some staff members do } \\
\text { not give enough office hours to students. Little practical work and a lot of theory is } \\
\text { taught. It is better to depend on repetitive frequent quizzes to help students retain the } \\
\text { information they learn. Students are creative, but this is not utilized in the learning } \\
\text { process. }\end{array}$ \\
\hline 3 & $\begin{array}{l}\text { Has been working at } \\
\text { Shoubra for more } \\
\text { than 26 years as } \\
\text { support staff }\end{array}$ & $\begin{array}{l}\text { Some students do not pay attention while others do care about studying. It is a } \\
\text { motivation problem. }\end{array}$ \\
\hline
\end{tabular}

Parents

\begin{tabular}{|c|c|c|}
\hline No. & Attributes & Response \\
\hline 1 & $\begin{array}{l}\text { Mother of a fresh } \\
\text { graduate }\end{array}$ & Increase the practical training in industrial sites \\
\hline 2 & $\begin{array}{l}\text { Father of a current } \\
\text { student }\end{array}$ & $\begin{array}{l}\text { Increase the practical training. Send students for training at large national and international } \\
\text { projects during the inter semester and summer vacations. I am willing to pay for training of } \\
\text { my son. The engineer should graduate with at least } 60 \% \text { practical experience and the } \\
\text { remainder } 40 \% \text { can be acquired after graduation. Engineers now lack experience. }\end{array}$ \\
\hline 3 & $\begin{array}{l}\text { Father of a fresh } \\
\text { graduate }\end{array}$ & $\begin{array}{l}\text { Practical education and hands on experience where students can implement their solutions. } \\
\text { Workshops or simulators may also help. The university should collaborate with large firms } \\
\text { to organize student visits. Some graduates lack enough knowledge in their specialties as } \\
\text { they were not trained during studying. }\end{array}$ \\
\hline 4 & $\begin{array}{l}\text { Father of a fresh } \\
\text { graduate from a } \\
\text { private university }\end{array}$ & Actual practical training under the supervision of faculty. \\
\hline 5 & $\begin{array}{l}\text { Father of a fresh } \\
\text { graduate }\end{array}$ & $\begin{array}{l}\text { Practical application for all specialties. } \\
\text { Renewal of study topic to be in line with the latest published scientific research. } \\
\text { Course design and implementation are not adequate }\end{array}$ \\
\hline
\end{tabular}

\section{Copyrights}

Copyright for this article is retained by the author(s), with first publication rights granted to the journal.

This is an open-access article distributed under the terms and conditions of the Creative Commons Attribution license which permits unrestricted use, distribution, and reproduction in any medium, provided the original work is properly cited. 